\title{
Selectivity of insecticides used in soybean crop to the predator Podisus nigrispinus (Hemiptera: Pentatomidae)
}

\section{Seletividade de inseticidas utilizados na cultura da soja ao predador Podisus nigrispinus (Hemiptera: Pentatomidae)}

\author{
Cristiane dos Santos Stecca ${ }^{1}$; Débora Mello da Silva ${ }^{2 *}$; Adeney de Freitas Bueno \\ Amarildo Pasini ${ }^{4}$; Marlon Dias Denez ${ }^{5}$; Karine Andrade ${ }^{6}$
}

\begin{abstract}
The selectivity of different insecticides to nymphs and adults of Podisus nigrispinus was evaluated in this study. Tests were carried out in the laboratory according to IOBC standard protocol. We evaluated different active ingredients that were applied using a Potter tower. Insect survival was assessed at 24-hour intervals for up to five days after exposure to treatments. Adult survivors of each treatment were assigned to breeding-pairs to evaluate possible effects on fertility. The pyrethroids bifenthrin, zeta-cypermethrin, beta-cyfluthrin, lambda-cyhalothrin and deltamethrin alone or in mixtures with neonicotinoids and diamides, such as beta-cyfluthrin + imidacloprid, lambda-cyhalothrin + thiamethoxan and chlorantraniliprole + lambda-cyhalothrin, as well as the organophosphate, chlorpyrifos, were the most harmful (class 4 classification) insecticides for the preservation of P. nigrispinus for both nymph and adult predators. Conversely, the insecticide growth regulators (IGRs) lufenuron, teflubenzuron, triflumuron, tebufenozide and novaluron were classified as harmful (class 4) only for P. nigrispinus nymphs. These products were classified as harmless (class 1) and slightly harmful (class 2) for adult predators. Among the evaluated products, the most selective for $P$. nigrispinus were those belonging to the spinosyns (spinosad and spinetoram) and the diamides group (flubendiamide and chlorantraniliprole), which were classified as harmless (class 1) and slightly harmful (class 2) for both P. nigrispinus nymphs and adults. Next, the most selective product was methoxyfenozide, which ranged between slightly harmful (class 2) and moderately harmful (class 3) to nymphs and harmless (class 1) to adults of the natural enemy.
\end{abstract}

Key words: Biological control. Chemical control. Natural enemy. IOBC.

\section{Resumo}

A seletividade de diferentes inseticidas para ninfas e adultos de Podisus nigrispinus foi avaliada neste estudo. Os testes foram realizados em laboratório de acordo com protocolo padrão da IOBC. Foram avaliados diferentes ingredientes ativos que foram aplicados usando uma torre Potter. A sobrevivência dos insetos foi avaliada em intervalos de 24 horas por até cinco dias após a exposição aos tratamentos. Os sobreviventes adultos de cada tratamento foram distribuídos em casais para avaliar possíveis efeitos

${ }^{1}$ Eng $^{\text {a }}$ Agr $^{\mathrm{a}}$, Dr ${ }^{\mathrm{a}}$, Universidade Estadual de Londrina, UEL, Londrina, PR, Brasil. E-mail: cristiane_stecca@yahoo.com.br

2 Bióloga, Dra ${ }^{a}$, Instituto Agronômico do Paraná, IAPAR, Londrina, PR, Brasil. E-mail: E-mail: deboramellosilva@gmail.com

${ }^{3}$ Eng $^{\circ}$ Agr $^{\circ}$, Dr., Pesquisador, Empresa Brasileira de Pesquisa Agropecuária, EMBRAPA Soja, Londrina, PR, Brasil. E-mail: adeney.bueno@embrapa.br

${ }^{4}$ Eng $^{\mathrm{O}}$ Agr $^{\circ}$, Prof. Dr., Departamento de Agronomia, CCA, UEL, Londrina, PR, Brasil. E-mail: pasini@uel.br

${ }^{5}$ Eng $^{\circ}$ Agr $^{\circ}$, M. e, Programa de Pós-Graduação em Agronomia, UEL, Centro de Ciências Agrárias, Departamento de Agronomia, Londrina, PR, Brasil. E-mail: marlondenez@hotmail.com

${ }^{6}$ Eng $^{\mathrm{a}}$ Agr ${ }^{\mathrm{a}}$, M.e, Programa de Pós-Graduação em Agronomia, UEL, Centro de Ciências Agrárias, Departamento de Agronomia, Londrina, PR, Brasil. E-mail: karine andrade16@hotmail.com

* Author for correspondence 
sobre a fertilidade. Os piretróides bifentrina, zeta-cipermetrina, beta-citflutrina, lambda-cialotrina e deltametrina isolados ou em misturas com neonicotinóides e diamidas, tais como beta-citflutrina + imidacloprid, lambda-cialotrina + tiametoxano e clorantraniliprole + lambda-cialotrina, bem como o organofosforado, clorpirifós, foram os inseticidas mais nocivos (classe 4) para a preservação de ninfas e adultos do predador P. nigrispinus. Por outro lado, os reguladores de crescimento de inseticidas (IGRs) lufenuron, teflubenzuron, triflumuron, tebufenozide e novaluron foram classificados como nocivos (classe 4) apenas para ninfas de P. nigrispinus. Estes produtos foram classificados como inofensivos (classe 1) e levemente nocivo (classe 2) para os predadores adultos. Entre os produtos avaliados, os mais seletivos para P. nigrispinus foram aqueles pertencentes às espinosinas (spinosad e spinetoram) e ao grupo das diamidas (flubendiamida e clorantraniliprole) classificados como inofensivos (classe 1) e levemente nocivos (classe 2) para ninfas e adultos de P. nigrispinus. Em seguida, o produto mais seletivo foi methoxyfenozide, que variou entre ligeiramente prejudicial (classe 2) e moderadamente prejudicial (classe 3) para ninfas e inofensivo (classe 1) para adultos do inimigo natural.

Palavras-chave: Controle Biológico. Controle químico. Inimigo natural. IOBC.

\section{Introduction}

In the last decades, soybean [Glycine max (L.) Merrill] farming is among the economic activities that has considerable growth worldwide. The importance of this crop has been emphasized due to the increase in the global demand for food and the diverse uses of this grain (LAZZAROTTO; HIRAKURI, 2010).

Among the pests that can reduce soybean yield and, therefore, require control to keep outbreaks below economic injury levels (EILs), caterpillars are of great concern, both due to more recent introductions of species, such as Helicoverpa armigera (Hübner) in Brazilian agriculture, as well as outbreaks of difficult control species, such as Spodoptera frugiperda (Smith), Spodoptera eridania (Cramer) and Chrysodeixis includens (Walker) (CORRÊA-FERREIRA et al., 2010; BUENO et al., 2011; CZEPAK et al., 2013). Those species, particularly $H$. armigera, have triggered economic losses, mainly due to management difficulties, and good control results have not been achieved even with the intensive use of chemicals (ÁVILA et al., 2013, EMBRAPA, 2014).

Therefore, different management tools should be used, among which biological control stands out in integrated pest management (IPM) because it is ecologically more sustainable when compared to conventional chemical control. In natural biological control, the insect predator Podisus nigrispinus
(Dallas) (Hemiptera: Pentatomidae) is an important biological control agent in Soybean-IPM because it plays an important role in the control of different lepidopteran pests (TORRES et al., 2006) and has large consumption capacity of other pest species (DENEZ et al., 2014). Despite the importance of biological control, chemical control might still be necessary. In such cases, the use of chemical control should be compatible with the preservation of the natural biological control agent. Thus, the most suitable insecticides for use in IPM are those that combine efficient pest control with low impact to beneficial arthropods (predators and parasitoids) (BUENO; FREITAS, 2004).

It is important to note that the impact of pesticides on beneficial insects includes both lethal and sublethal effects (DESNEUX et al., 2007). Therefore, the evaluation of pesticide selectivity should include not only lethal effects on the biological control agents but also possible side effects on their fecundity and viability. In this context, the objective of this study was to evaluate the selectivity of different insecticides used in the soybean crop against the predator $P$. nigrispinus under laboratory conditions including lethal and sub-lethal effects.

\section{Material and Methods}

Caterpillars of the genus Spodoptera and the species Anticarsia gemmatalis (Hübner) 
(Lepidoptera: Erebidae) were used as prey. These caterpillars, along with the insect predator $P$. nigrispinus used in the experiments, were reared in the laboratory under controlled conditions $(25 \pm$ $2^{\circ} \mathrm{C}, 70 \pm 10 \% \mathrm{RH}$, and photophase of $14 \mathrm{~h}$ ).

Selectivity trials were carried out with predator nymphs and adults ( $\leq 24$ hours of age), in the laboratory under controlled conditions $\left(25 \pm 2{ }^{\circ} \mathrm{C}\right.$, $70 \pm 10 \% \mathrm{RH}$, and photophase of $14 \mathrm{~h}$ ). Insects were exposed to different treatments divided into 3 bioassays (Table 1), according to protocols standardized by the International Organization of Biological Control (IOBC). In the experiments with nymphs, insects of the $4^{\text {th }}$ instar were used because they were of an intermediate size and were therefore easier to manage.

The experimental design was completely randomized with 6,9 and 10 treatments (Table 1) in bioassays 1, 2 and 3, respectively. There were 50 replicates in each treatment, each consisting of one insect according to the studied development stage (nymph or adult). Treatments consisted of insecticides used for soybean management at the highest recommended rate for the crop (Table 1), a control (distilled water), and an insecticide known to be harmful to different natural enemies (chlorpyrifos) (BUENO et al., 2008; CARMO et al., 2010) as comparison standards.

Table 1. Insecticides tested against Podisus nigrispinus under controlled environmental conditions in the laboratory.

\begin{tabular}{ccccc}
\hline Active ingredient (a.i.) & Commercial name & Chemical group & $\mathbf{C}^{\mathbf{1}}$ & g. a.i. ha $^{-\mathbf{1}}$ \\
\hline Beta-cyfluthrin & Bulldock 125 SC & Pyrethroid & 125 & 7.5 \\
Beta-cyfluthrin + imidacloprid & Connect & Pyrethroid + neonicotinoid & $12.5+100$ & $100+12.5$ \\
Bifenthrin & Talstar 100 EC & Pyrethroid & 100 & 5 \\
Chlorantraniliprole & Premio & Diamide & 200 & 10 \\
Chlorantraniliprole + & Ampligo & Diamide + pyrethroid & $100+50$ & $7.5+3.75$ \\
lambda-cyhalothrin & Atabron 50 EC & Benzoilureis & 50 & 37.5 \\
Clorfluazuron & Lorsban 480 CE & Organophosphates & 480 & 480 \\
Chlorpyrifos & Decis 25 EC & Pyrethroid & 25 & 7.5 \\
Deltamethrin & Exalt & Spinosyns & 120 & 3 \\
Spinetoram & Tracer 480 SC & Spinosyns & 480 & 24 \\
Spinosad & Belt & Diamide & 480 & 33.6 \\
Flubendiamide & Karate Zeon 250 CS & Pyrethroid & 250 & 7.5 \\
Lambda-cyhalothrin & Engeo Pleno & Pyrethroid + neonicotinoid & $106+141$ & $21.2+28.2$ \\
Lambda-cyhalothrin + & Match CE & Benzoilureis & 50 & 7,5 \\
thiamethoxan & Intrepid 240SC & Diacylhydrazine & 240 & 21.6 \\
Lufenuron & Rimon EC 100 & Benzoilureis & 100 & 7.5 \\
Methoxyfenozide & Mimic 240 SC & Diacylhydrazine & 240 & 30 \\
Novaluron & Nomolt 150 & Benzoilureis & 150 & 7.5 \\
Tebufenozide & Certero & Benzoilureis & 480 & 14.4 \\
Teflubenzuron & Pyrethroid & 350 & 35 \\
Triflumuron & Mustang 350 EC & &
\end{tabular}

${ }^{1}$ Concentration of the active ingredient in $\mathrm{g} \mathrm{L}^{-1}$. 
The selectivity bioassays for nymphs were performed on glass plates $(13 \times 13 \mathrm{~cm})$, on the surface of which each product was applied using a Potter's tower, calibrated to deposit $1.75 \pm 0.25$ $\mathrm{mg} \mathrm{cm} \mathrm{cm}^{2}$ (HASSAN et al., 2000; MANZONI et al., 2007). Deposition was controlled using a precision balance weighing the glass plate before and after spraying (CARMO et al., 2010).

After spraying, the glass plates were allowed to dry for a two-hour period at $25 \pm 2{ }^{\circ} \mathrm{C}$ and relative humidity of $70 \pm 10 \%$. Then, a circular area was delimited in each glass plate with the aid of a polyvinyl chloride (PVC) arena with a height of 3 $\mathrm{cm}$ and a diameter of $7.5 \mathrm{~cm}$. The inner surface of the ring was treated with vaseline, to prevent insect escape from the treated area, thus ensuring that the nymphs remained in contact with the treated glass plate. The nymphs were released onto the glass plates, and the upper end of the arena was protected with a fine tissue (voile), which also helped prevent insect escape.

P. nigrispinus adults were also tested using similar insecticide spray protocols, but unlike the nymphs, the adults received direct sprays. Treatment application was achieved by attaching the predator to the glass plate with the aid of the PVC ring, where the protection of the upper end of the ring was replaced with $1.5 \mathrm{~mm}^{2}$ mesh tissue, to allow the insecticide under evaluation to have adequate coverage of the applied surface. This procedure was adopted to prevent the insects from being anesthetized with $\mathrm{CO}^{2}$ or low temperatures, ensuring that their physiology was not altered, thus avoiding an increase in their susceptibility to the action of insecticides.

Evaluations were conducted at intervals of 24 hours up to five days after insecticide spray, for nymphs and adults, as recommended for predators in the IOBC standard protocols (OVERMEER; VAN ZON, 1985; VIÑUELA et al., 2000). After the exposure of the insects to the respective treatments, the survival rate was evaluated. During this period, the predators were fed daily with third instar caterpillars of $A$. gemmatalis. Adults that survived to each treatment were assigned to the maximum number of possible breeding-pairs formed among insects under the same treatment. The number of breeding-pairs formed varied between the different treatments, ranging from at least 5 for the most harmful products to 25 for the control and for more selective products. These pairs were kept in cages for a period of 10 days, during which time the insects presented greater oviposition capacity (DENEZ et al., 2014) to evaluate possible effects on fertility, according to protocols standardized by IOBC, described by Viñuela et al. (2000).

The total effect of the product on nymphs and adults was calculated using the index of Overmeer and Van Zon (1985) where: E1 = 100\% - (100\% $-\mathrm{M} \%)$ x R1 in which; E1 = Total effect (\%); M\%= Control-corrected mortality (ABBOTT, 1925) and $\mathrm{R} 1=$ Ratio between the mean daily number of eggs laid per treated and untreated female; and E2 $=100 \%$ - (100\%-M\%) x R2 modified from (OVERMEER; VAN ZON, 1985) where $\mathrm{R} 2$ = ratio of daily average viable eggs per treated and untreated female. Subsequently, the products were categorized into the following classes of toxicity: class $1=$ harmless $(\mathrm{E}<30 \%)$, class $2=$ slightly harmful $(30 \% \leq \mathrm{E}<80)$, class $3=$ moderately harmful $(80 \% \leq \mathrm{E}<99)$ and

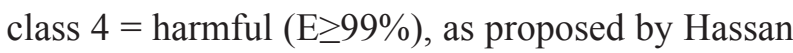
(1992). Additionally, regression analysis was performed on the data obtained for each treatment evaluated.

\section{Results and Discussion}

The pyrethroids bifenthrin, zeta-cypermethrin, beta-cyfluthrin, lambda-cyhalothrin and deltamethrin alone or in mixtures with neonicotinoids or diamides such as beta-cyfluthrin + imidacloprid, lambda-cyhalothrin + thiamethoxam and chlorantraniliprole + lambda-cyhalothrin, as well as the organophosphate chlorpyrifos were the most harmful insecticides to $P$. nigrispinus 
(Figures 1, 2 and 3) and were classified as harmful (class 4) for both nymphs and adults of the insect predator P. nigrispinus (Table 2). Pyrethroids have a neurotoxic action common to arthropods and thus have a broad spectrum. These insecticides are generally classified as non-selective to most of the beneficial arthropod species (CARMO et al., 2010), although this designation is not precise because the insecticide effect varies among species and even among the developmental stages of the same species (BUENO et al., 2017). However, the harmful effect of the pyrethroids is confirmed in this study, as all the different pyrethroids tested were highly toxic regardless of the predator's life stage. Similarly, the neonicotinoids also have neurotoxic effects in insects, and although they act differently in the nervous system, the neonicotinoids are also considered harmful to most of the natural enemies (TOMIZAWA, CASIDA, 2005; TALEBIJAHROMI, 2007). The main difference between these two chemical groups is that the pyrethroids have a contact action, which makes them even more harmful to the different organism's in the crop. Conversely, neonicotinoids are systemic products with little contact action. These insecticides need to be ingested by insects and therefore, are more specific against phytophagous sucking insects, which, due to their feeding habits, come into contact with the product when feeding on the sap of the plants. Since beneficials insects usually do not feed on plants, neonicotinoids may have greater ecological selectivity (SANTOS et al., 2006) when compared to pyrethroids.

Insecticides from the insect growth regulators (IGRs) group, such as lufenuron, teflubenzuron, triflumuron, tebufenozide and novalurom, were harmful in the bioassay with nymphs (Figure 2A) but harmless to adults (Figure 2B). Therefore, these insecticides are classified as harmful (class 4) only for nymphs of $P$. nigrispinus and as harmless (class 1) and slightly harmful (class 2) for adults of the predator (Table 2). The IGRs are insecticides generally classified as harmless to natural biological control agents (SILVA et al., 1988, SANTOS et al., 2006). However, although these chemicals affect specific hormones that trigger the physiological process responsible for insect ecdysis (CARMO et al., 2010; BUENO et al., 2017), they may also act on the young stage of natural enemies, and not only of the pests, depending on the product and insecticide rate under evaluation (BUENO et al., 2008), as demonstrated in this study. Moreover, although the potential action of these insecticides is greater for the immature phase of the insect (BUENO et al., 2008; PFEIFFER, 2014), some IGRs may have a transovarian effect in adults of some insect pests and natural enemies. Lufenuron is an example of a growth regulator that has been demonstrated to have transovarian activity for Plutella xylostella (Lepidoptera: Plutellidae), as reported by De Bortoli et al. (2006). This effect on fertility was also observed for the predator Chrysoperla externa (Neuroptera: Chrysopidae) after ingestion of the insecticide (BUENO; FREITAS, 2004). Thus, despite the greater selectivity to the adult stage, those products might also have sublethal effects on adults. The higher IGRs selectivity to adults may be related to the higher degradation capacity of the molecule by the $P$. nigrispinus adult and thus, its ability to avoid direct contamination or deleterious effects in later generations (PEREIRA et al., 2005). 


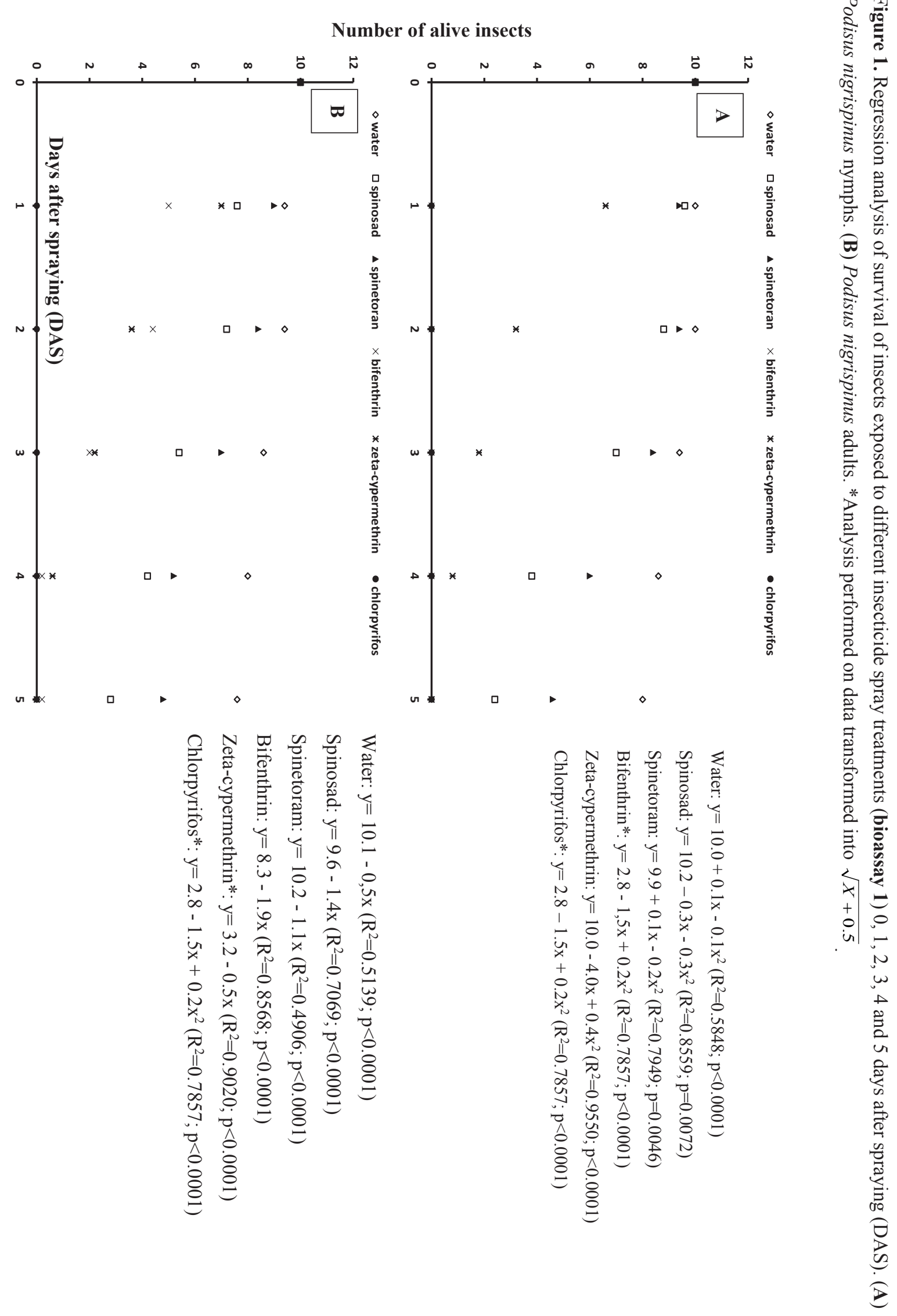




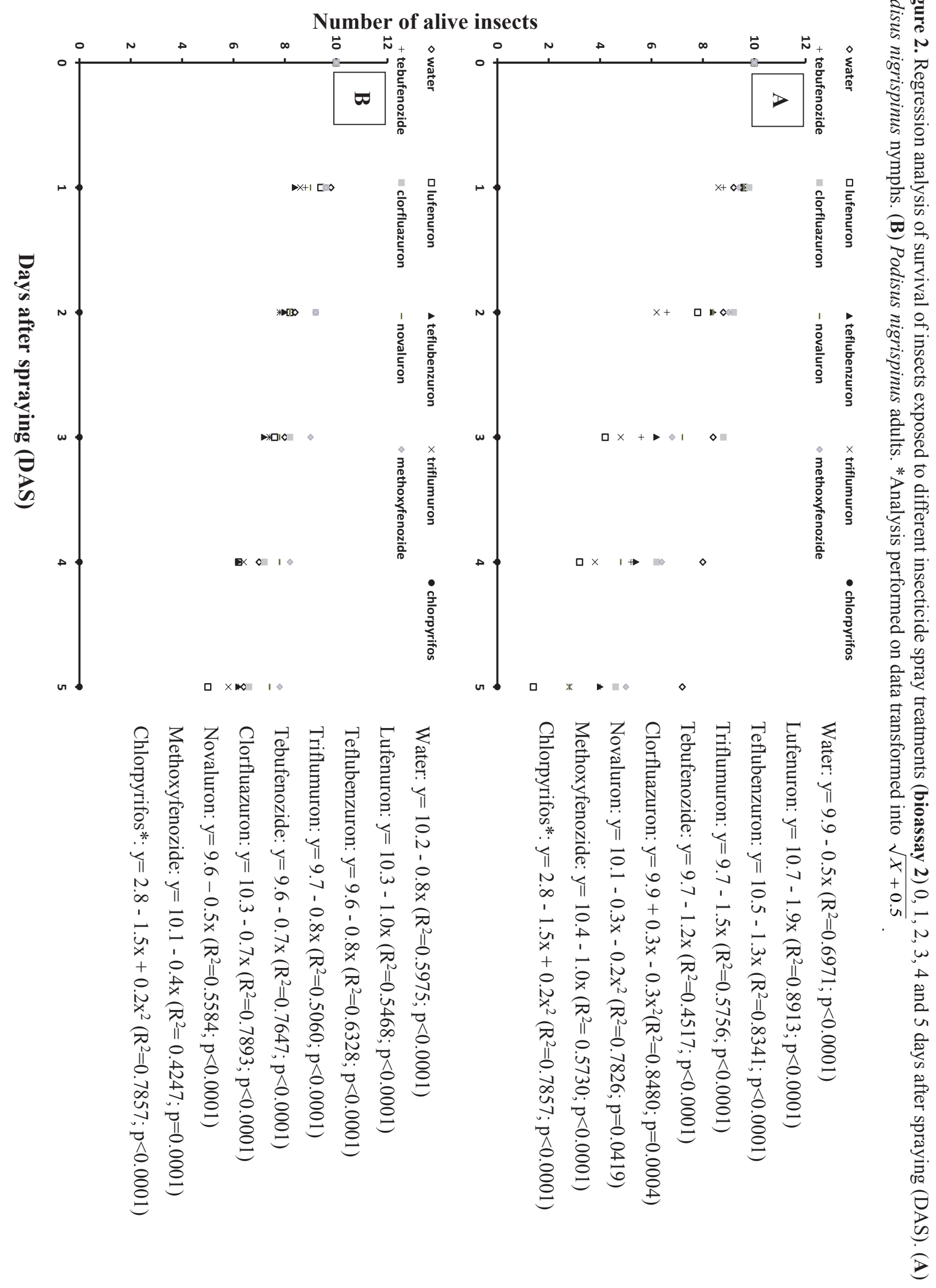

Semina: Ciências Agrárias, Londrina, v. 38, n. 6, p. 3469-3480, nov./dez. 2017 


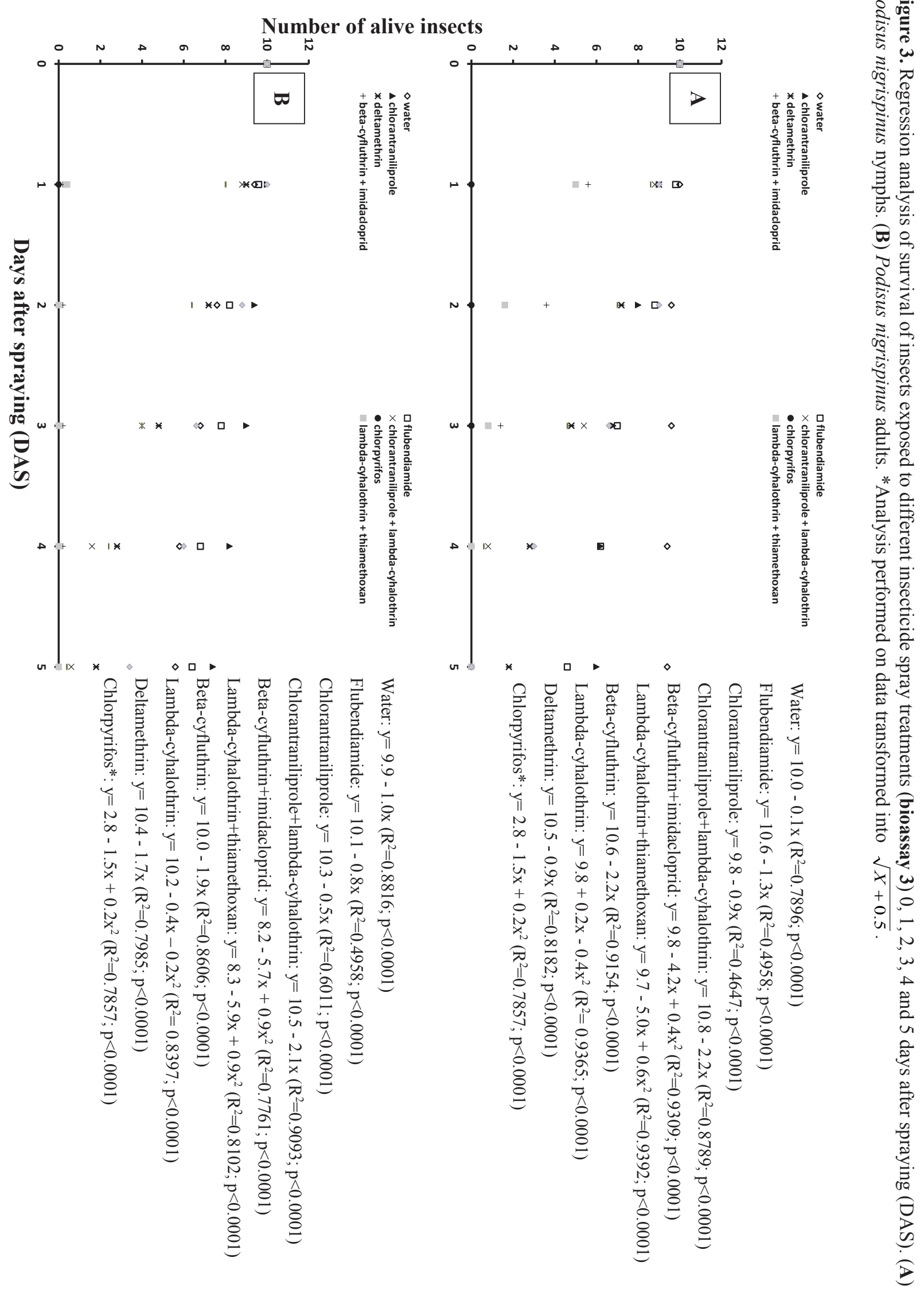


Table 2. Effect of different insecticides on Podisus nigrispinus and their classification according to the norms of the International Organization for Biological Control (IOBC).

\begin{tabular}{|c|c|c|c|c|c|c|c|c|c|}
\hline \multirow{2}{*}{\multicolumn{2}{|c|}{$\begin{array}{l}\text { Treatment g a.i. } 200 \mathrm{~L} \mathrm{ha}^{-1} \\
\text { E1\% }\end{array}$}} & \multicolumn{4}{|c|}{40 instar nymph } & \multicolumn{4}{|c|}{ Adult } \\
\hline & & $\mathrm{C1}^{2}$ & E2\% ${ }^{3}$ & $\mathrm{C2}^{2}$ & E1\% ${ }^{1}$ & $\mathrm{C1}^{2}$ & E2\% $\%^{3}$ & $\mathrm{C2}^{2}$ & \\
\hline \multirow{5}{*}{ 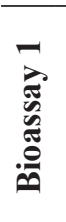 } & Spinosad 24 & 78 & 2 & 20 & 1 & 53 & 2 & 50 & 2 \\
\hline & Spinetoram 3 & 10 & 1 & 0 & 1 & 38 & 2 & 0 & 1 \\
\hline & Bifenthrin 5 & 100 & 4 & 100 & 4 & 100 & 4 & 100 & 4 \\
\hline & Zeta-cypermethrin 35 & 100 & 4 & 100 & 4 & 100 & 4 & 100 & 4 \\
\hline & Chlorpyrifos 480 & 100 & 4 & 100 & 4 & 100 & 4 & 100 & 4 \\
\hline \multirow{8}{*}{ 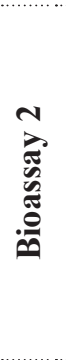 } & Lufenuron 7.5 & 100 & 4 & 100 & 4 & 41.53 & 2 & 39.15 & 2 \\
\hline & Teflubenzuron 7.5 & 100 & 4 & 100 & 4 & 13.38 & 1 & 32.56 & 2 \\
\hline & Triflumuron 14.4 & 100 & 4 & 100 & 4 & 29.76 & 1 & 22.01 & 1 \\
\hline & Tebufenozide 30 & 100 & 4 & 100 & 4 & 56.07 & 2 & 46.84 & 2 \\
\hline & Clorfluazuron 37.5 & 47 & 2 & 68 & 2 & 0 & 1 & 0 & 1 \\
\hline & Novaluron 7.5 & 100 & 4 & 100 & 4 & 0 & 1 & 0 & 1 \\
\hline & Methoxyfenozide 21.6 & 66 & 2 & 95 & 3 & 0 & 1 & 0 & 1 \\
\hline & Chlorpyrifos 480 & 100 & 4 & 100 & 4 & 100 & 4 & 100 & 4 \\
\hline \multirow{9}{*}{ 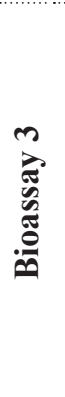 } & Flubendiamide 33.6 & 35 & 2 & 28 & 1 & 30 & 2 & 43 & 2 \\
\hline & Chlorantraniliprole 10 & 58 & 2 & 62 & 2 & 4 & 1 & 0 & 1 \\
\hline & Chlorantraniliprole $7.5+$ lambda-cyhalothrin 3.75 & 100 & 4 & 100 & 4 & 100 & 4 & 100 & 4 \\
\hline & Beta-cyfluthrin 12.5 + imidacloprid 100 & 100 & 4 & 100 & 4 & 100 & 4 & 100 & 4 \\
\hline & Lambda-cyhalothrin $21.2+$ thiamethoxan 28.2 & 100 & 4 & 100 & 4 & 100 & 4 & 100 & 4 \\
\hline & Beta-cyfluthrin 7.5 & 100 & 4 & 100 & 4 & 100 & 4 & 100 & 4 \\
\hline & Lambda-cyhalothrin 7.5 & 100 & 4 & 100 & 4 & 100 & 4 & 100 & 4 \\
\hline & Deltamethrin 7.5 & 100 & 4 & 100 & 4 & 100 & 4 & 100 & 4 \\
\hline & Chlorpyrifos 480 & 100 & 4 & 100 & 4 & 100 & 4 & 100 & 4 \\
\hline
\end{tabular}

${ }^{1} \mathrm{E} 1=100 \%-(100 \%-M \%) R 1(O V E R M E E R ;$ VAN ZON, 1985) where E1 = Total effect (\%); M\% = Mortality corrected by the control (Abbott, 1925); R1 = ratio between daily mean of eggs laid per treated and untreated female. ${ }^{2} \mathrm{Class} 1=$ harmless $(\mathrm{E}<30 \%)$, class $2=$ slightly harmful $(30 \% \leq \mathrm{E}<80)$, class $3=$ moderately harmful $(80 \% \leq \mathrm{E}<99)$, class $4=$ harmful $(\mathrm{E} \geq 99 \%) .{ }^{3} \mathrm{E} 2=100 \%$ - (100\%-M\%) R2 (modified from OVERMEER; VAN ZON, 1985) where R2 = Mean daily viable egg ratio per treated and untreated female.

Among the evaluated products, the most selective for $P$. nigrispinus were those belonging to the spinosyns (spinosad and spinetoram) group (Figure 1) as well as the diamides group (flubendiamide and chlorantraniliprole) (Figure 3), which were classified as harmless (class 1) and slightly harmful (class 2) for both nymphs and adults of $P$. nigrispinus (Table 2). Spinosad is an insecticide derived from a mixture of spinosyns A and D, which are tetracyclic macrolide compounds produced by the actinomycete Saccharopolyspora spinosa. Spinosad's use in organic crops is permitted in many countries. This insecticide acts primarily as an ingestion insecticide with some contact activity (BRET et al., 1997). Like the results obtained in this study, spinosad is frequently classified with environmental and toxicological reduced risk and generally less harmful to predators, although with less selectivity to Hymenoptera parasitoids, which are significantly more susceptible to their effects (WILLIAMS et al., 2003). Spinetoram is very similar to spinosad just because chemical characteristics of both are similar. Like spinosyn, the diamides are cited as selective for various natural enemies, from beetles to predatory mites (FONSECA et al., 2012; REIS et al., 2011). The insecticides of this group are very selective because they will act more specifically on insects of the order Lepidoptera and are considered safe for non-target organisms, mainly mammals and natural enemies (LAHM et al., 2009). The most 
selective product was methoxyfenozide (Figure 2), which ranged between slightly harmful (class 2) and moderately harmful (class 3 ) for nymphs and harmless (class 1) for adults of P. nigrispinus (Table 2).

The differences observed in insecticide selectivity for different development stages of predator may be related to the site of action of each insecticide that can change during development, affecting penetration rate through the integument and /or its metabolization by the insect (BUENO et al., 2017). The penetration rate of each insecticide through the integument results from the relationship between the affinity of the evaluated insecticides and the thickness and chemical composition of the integument of the natural enemy (FERNANDES et al., 2010). The lipophilicity of the insecticides is inversely proportional to their solubility in water. Therefore, compounds of higher lipophilicity can penetrate the insect's body at higher rates because of its similarity to the cuticle, resulting in different penetration rates in the nymph and the adult cuticle of the predator, which needs to be studied in more detail in future experiments.

It is important to note that the application of broad-spectrum insecticides (such as pyrethroids and organosphorates) at the beginning of the soybean cycle, often with reduced populations of insects, will only represent an unnecessary cost. This application diminishes the potential of beneficial arthropods, as demonstrated in this work, and may allow the resurgence and occurrence of pests at higher population levels (CORRÊA-FERREIRA et al., 2010). Torres and Ruberson (2004) verified the harmful effects of the broad-spectrum insecticides for $P$. nigrispinus nymphs, which were highly sensitive to thiamethoxam and imidacloprid, while Torres et al. (2002) verified the harmful effects of thiamethoxam and other neurotoxic activities.

\section{References}

ABBOTT, W. S. A method of computing the effectiveness of an insecticide. Journal of Economic Entomology, Lanham, v. 18, n. 1, p. 265-267, 1925.

ÁVILA, C. J.; VIVAN, L. M.; TOMQUELSKI, G. V. Ocorrência, aspectos biológicos, danos e estratégias de manejo de Helicoverpa armigera (Hübner) (Lepidoptera: Noctuidae) nos sistemas de produção agrícolas. Dourados: Embrapa Agropecuária Oeste. 2013, 12 p. (Embrapa Agropecuária Oeste. Circular técnica, 23).

BRET, B. L.; LARSON, L. L.; SCHOONOVER, J. R.; SPARKS, T.C.; THOMPSON, G. D. Biological properties of spinosad. Down to Earth, New Delhi, v. 52, n. 1, p. 6-13, 1997.

BUENO, A. F.; FREITAS, S. Effect of the insecticides abamectin and lufenuron on eggs and larvae of Chrysoperla externa under laboratory conditions. BioControl, Dordrech, v. 39, n. 3, p. 277-283, 2004.

BUENO, A. F.; BATISTELA, M. J.; BUENO, R. C. O. F.; FRANÇA-NETO, J. B.; NISHIKAWA, M. A. N.; LIBÉRIO FILHO, A. Effects of integrated pest management, biological control and prophylactic use of insecticides on the management and sustainability of soybean. Crop Protection, Kidlington, v. 30, n. 7, p. 937 945, 2011.

BUENO, A. F.; BUENO, R. C. O. F.; PARRA, J. R. P.; VIEIRA, S. S. Effects of pesticides used in soybean crops to the egg parasitoid Trichogramma pretiosum. Ciência Rural, Santa Maria, v. 38, n. 6, p. 1495-1503, 2008.

BUENO, A. F.; CARVALHO, G. A.; SANTOS, A. C.; SOSA-GÓMEZ, D. R.; SILVA, D. M. Pesticide selectivity to natural enemies: challenges and constraints for research and field recommendation. Ciência Rural, Santa Maria, v. 47, n. 6, p. 1-8, 2017.

CARMO, E. L.; BUENO, A. F.; BUENO, R. C. O. F.; VIEIRA, S. S.; GOULART, M. M. P.; CARNEIRO, T. R. Seletividade de produtos fitossanitários utilizados na cultura da soja para pupas de Trichogramma pretiosum Riley, 1879 (Hymenoptera: Trichogrammatidae). Arquivos do Instituto Biológico, São Paulo, v. 77, n. 2, p. 283-290, 2010.

CORRÊA-FERREIRA, B. S.; ALEXANDRE, T. M.; PELLIZZARO, E. C.; MOSCARDI, F.; BUENO, A. F. Práticas de manejo de pragas utilizadas na soja e seu impacto sobre a cultura. Londrina: EMBRAPA-CNPSo, 2010. (Embrapa Soja, Circular técnica, 78). 
CZEPAK, C.; ALBERNAZ, K. C.; VIVAN, L. M.; GUIMARÃES, H. O.; CARVAlHAIS, T. Primeiro registro de ocorrência de Helicoverpa armigera (Hübner) (Lepidoptera: Noctuidae) no Brasil. Pesquisa Agropecuária Tropical, Goiânia, v. 43, n. 1, p. 110-113, 2013.

DE BORTOLI, A. S.; THULER, R. T.; LOPES, B. S. Efeito de lufenuron e azadiractina sobre adultos de Plutella xylostella (Lepidoptera: Plutellidae). Cientifica, Jaboticabal, v. 34, n. 1, p. 53-58, 2006.

DENEZ, M. D.; BUENO, A. F.; PASINI, A.; BORTOLOTTO, O. C.; STECCA, C. S. Biological parameters of Podisus nigrispinus (Hemiptera: Pentatomidae) fed with different soybean insect pests. Annals of Entomological Society of America, Annapolis, v. 107, n. 5, p. 967-974, 2014.

DESNEUX, N.; DECOURTYE, A.; DELPUECH, J. M. The sublethal effects of pesticides on beneficial arthropods. Annual Review of Entomology, Palo Alto, v. 52, n. 1, p. 81-106, 2007.

EMPRESA BRASILEIRA DE PESQUISA AGROPECUÁRIA - EMBRAPA. Ações emergenciais propostas pela Embrapa para o manejo integrado de Helicoverpa spp. em áreas agrícolas. Rio de Janeiro: Embrapa, 2013. Disponível em: <http://www.embrapa. br/alerta-helicoverpa/Manejo-Helicoverpa.pdf $>$. Acesso em: 21 nov. 2015.

FERNANDES, F. L.; BACCI, L.; FERNANDES, M. S. Impact and selectivity of insecticides to predators and parasitoids. EntomoBrasilis, Piracicaba, v. 3, n. 1, p. 1-10, 2010.

FONSECA, P. R. B.; MOTA, T. A.; KASSAB, S. O.; FERNANDES, M. G. Seletividade de inseticidas utilizados no controle da Spodoptera frugiperda (J.E. Smith, 1797) nos inimigos naturais epigéicos na cultura do milheto. Revista Caatinga, Mossoró, v. 25, n. 1, p. 14-19, 2012.

HASSAN, S. A. Guideline for the evaluation of sideeffects of plant protection products on Trichogramma cacoeciae. In: (Ed.). Guidelines for testing the effects of pesticides on beneficial organisms: description of test methods. Dordrecht: IOBC/WPRS Bulletin, 1992. v. 15, p. $18-39$.

HASSAN, S.A.;HALSALL, N.; GRAY,A.P.; KUEHNER, C.; MOLL, M.; BAKKER, F. M.; ROEMBKE, J.; YOUSEF, A.; NASR, F.; ABDELGADER, H. A. A laboratory method to evaluate the side effects of plant protection products on Trichogramma cacoeciae Marchal (Hym, Trichogrammatidae). In: CANDOLFI, M.P.; BLÜMEL, S.; FORSTER, R.; BAKKER, F.M.;
GRIMM, C.; HASSAN, S.A.; HEIMBACH, U.; MEADBRIGGS, M.A.; REBER, B.; SCHMUCK R.; VOGT, H. (Ed.). Guidelines to evaluate side-effects of plant protection products to non-target arthropods. Reinheim: IOBC/WPRS, 2000.

LAHM, G. P.; CORDOVA, D.; BARRY, J. D. New and selective ryanodine receptor activators for insect control. Bioorganic \& Medicinal Chemistry, Oxford, v. 17, n. 12, p. 4127-4133, 2009.

LAZZAROTTO, J. J.; HIRAKURI, M. H. Evolução e perspectivas de desempenho econômico associadas com a produção de soja nos contextos mundial brasileiro. 2010. Londrina: Embrapa Soja (Embrapa Soja. Documentos, 319).

MANZONI, C. G.; GRÜTZMACHER, A. D.; GIOLO, F.P.; HÄRTER, W. R.; CASTILHOS, R. V. PASCHOAL, M. D. F. Seletividade de agroquímicos utilizados na produção integrada de maçã aos parasitóides Trichogramma pretiosum Riley e Trichogramma atopovirilia Oatan \& Platner (Hymenoptera: Trichogrammatidae). Bioassay, Piracicaba, v. 2, n. 1, p. 1-11, 2007.

OVERMEER, W. P. J.; VAN ZON, A. Q. Amblyseius potentillae (Garman) (Acarina: Phytoseiidae). In: Standard methods to test the side effects of pesticides on natural enemies of insects and mites. Bulletin OEPP, 15 p.214-255, 1985.

PEREIRA, A. I. A.; RAMALHO, F. S.; ZANUNCIO, J. C. Susceptibility of Podisus nigrispinus (Dallas) (Heteroptera: Pentatomidae) to gammacyhalothrin under laboratory condictions. Scientia Agricola, Piracicaba, v. 62, n. 5, p. 478-482, 2005.

PFEIFFER, M. Insect growth regulators. 2014. Disponível em: <http://www.ptrpest.com/pdf/igr.pdf>. Acesso em: 17 dez. 2015.

REIS, P. R.; FRANCO, R. A.; SILVA, F. M. A. Selectivity of rynaxypyr for three species of phytoseiid mites relevant to coffee in Brazil. Coffee Science, Lavras, v. 6, n. 3, p. 212-216, 2011.

SANTOS, A. C.; BUENO, A. F.; BUENO, R. C. O. F. Seletividade de defensivos agrícolas aos inimigos naturais. In: PINTO, A. S.; NAVA, D. E.; ROSSI, M. M.; MALERBO-SOUZA, D. T. (Ed.). Controle biológico de pragas na prática 1. Piracicaba: FEALQ, 2006. p. 221227.

SILVA, M. T. B.; CORSO, I. C.; BELARMINO, L. C.; LINK, D.; TONET, G. L.; GOMES, A. S.; SANTOS, B. Avaliação de inseticidas sobre predadores das pragas da soja, em dez anos agrícolas, no Brasil. Trigo e Soja, Porto Alegre, v. 96, n. 1, p. 3-16, 1988. 
TALEBI-JAHROMI, K. Pesticide toxicology. Tehran: University of Tehran Publication, 2007. 492 p.

TOMIZAWA, M.; CASIDA, J. E. Neonicotinoid insecticide toxicology: Mechanisms of selective action. Annual Review of Pharmacology and Toxicology, Palo Alto, v. 45, n. 1, p. 247-268, 2005.

TORRES, J. B., RUBERSON, J. R. Toxicity of thiamethoxam and imidacloprid to Podisus nigrispinus (Dallas) (Heteroptera: Pentatomidae) nymphs associated to aphid and whitefly control in cotton. Neotropical Entomology, Londrina, v. 33, n. 1, p. 99-106, 2004.

TORRES, J. B.; SILVA-TORRES, C. S. A.; SILVA, M. R.; FERREIRA, J. F. Compatibilidade de inseticidas e acaricidas com o percevejo predador Podisus nigrispinus (Dallas) (Heteroptera: Pentatomidae) em algodoeiro. Neotropical Entomology, Londrina, v. 31, n. 2, p. 311$317,2002$.
TORRES, J. B.; ZANUNCIO, J. C.; MOURA, M. A. The predatory stinkbug Podisus nigrispinus: biology, ecology and augmentative releases for lepidopteran larval control in Eucalyptus in Brazil. Biocontrol News and Information, Wallingford, v. 27, n. 3, p. 1-15, 2006.

VIÑUELA,E.;ADÁN,A.; SMAGGHE, G.; GONZÁLEZ, M.; MEDINA, M. P.; BUDIA, F.; VOGT, H.; ESTAL, P. Laboratory effects of ingestion of azadirachtin by two pests (Ceratitis capitata and Spodoptera exigua) and tree natural enemies (Chrysoperla carnea, Opius concolor and Podisus maculiventris). Biocontrol Science and Technology, Oxford, v. 10, n. 2, p. 165-177, 2000.

WILLIAMS, T.; VALLE, J.; VIÑUELA, E. Is the naturally derived insecticide spinosad ${ }^{\circledR}$ compatible with insect natural enemies? Biocontrol Science and Technology, Oxford, v. 13, n. 1, p. 459-475, 2003. 